\title{
Tafsir Kejadian 2:15 Sebagai Konstruksi Memahami Pelayanan dan Tanggung Jawab Orang Percaya terhadap Lingkungan
}

\author{
Bimo Setyo Utomo \\ Sekolah Tinggi Teologi Efrata Sidoarjo \\ samuel.bimo@gmail.com
}

DOI: https://doi.org/ 10.34307/b.v3i2.177

\begin{abstract}
Environmental damage has become a common problem for human beings who need serious attention, especially from believers who should be able to find a biblical basis for what to do in environmental preservation. In the status and function created by God, humans are not only the image of God, but also as God's coworkers. In Genesis 2:15, the Garden of Eden as a representation of human habitat at that time, was created by God for a noble purpose, which is to be cultivated and maintained by humans. Therefore, in an effort to find a theological basis for the role of believers in pursuing environmental sustainability, this study will discuss the meaning of the word strive and maintain the Garden of Eden through the exegesis method. The author analyzes the verbs, then presents an interpretation that is elaborated with various relevant sources. The result is theological findings that produce concepts about the service and responsibilities of believers in the environment.
\end{abstract}

Keyword: strive, mantain, environment, Garden of Eden, Genesis 2:15

\begin{abstract}
Abstrak: Kerusakan lingkungan telah menjadi masalah bersama umat manusia yang perlu mendapat perhatian serius, terutama dari orang percaya yang harusnya dapat menemukan dasar Alkitab mengenai apa yang harus dilakukan dalam upaya pelestarian lingkungan. Dalam status dan fungsinya diciptakan oleh Allah, manusia tidak hanya menjadi citra Allah, tetapi juga sebagai rekan sekerja Allah. Dalam Kejadian 2:15, Taman Eden sebagai representasi habitat manusia kala itu, disediakan oleh Allah untuk kepentingan manusia, yaitu dengan cara manusia mengusahakan dan memelihara Taman Eden tersebut. Oleh sebab itu, dalam upaya mencari dasar teologis mengenai peran orang percaya dalam mengupayakan kelestarian lingkungan, dalam penelitian ini akan dibahas mengenai makna kata mengusahakan dan memelihara Taman Eden melalui metode eksegesa. Penulis melakukan analisis terhadap kata kerja tesebut, kemudian melengkapinya dengan sebuah tafsiran yang didapat dari berbagai sumber yang bekaitan dengan nats Kejadian 2:15. Hasilnya adalah temuan teologis yang menghasilkan konsep tentang pelayanan dan tanggung jawab orang percaya terhadap lingkungan.
\end{abstract}

Kata Kunci: mengusahakan, memelihara, lingkungan, taman eden, Kejadian2:15

\begin{tabular}{llll}
\hline Article History : & Received: 16-06-2020 & Revised: 02-09-2020 Accepted:03-12-2020
\end{tabular}




\section{Pendahuluan}

Kehidupan umat manusia di dunia ini sangat bergantung dengan daya dukung lingkungan tempat mereka hidup, karenanya kemampuan dan kondisi lingkungan untuk terus dapat memberikan dukungan dan manfaat bagi kehidupan manusia harus benarbenar diperhatikan dan dijaga sebaik mungkin, karena lingkungan hidup tentu tidak dapat secara sepihak dan terus menerus mendukung jumlah kehidupan serta aktivitas tanpa batas dari manusia, sebab apabila lingkungan mengalami kerusakan atau sudah tidak mampu lagi mendukung kehidupan manusia, tentulah manusia akan menuai berbagai kesulitan, baik di kehidupan saat ini, maupun di kehidupan yang akan datang.

Dalam zaman yang semakin modern, permasalahan daya dukung lingkungan yang semakin memprihatinkan sebenarnya disebabkan oleh kerusakan lingkungan hidup yang mau tidak mau telah membuat membuat kondisi habitat manusia menjadi semakin memprihatinkan pula. Permasalahan kerusakan lingkungan ini merupakan sebuah permasalahan yang bersifat universal yang membawa seluruh umat manusia di bumi ini kepada keprihatinan yang sama dan semakin dalam dari tahun ke tahun. Kerusakan lingkungan tidak saja telah menurunkan kualitas hidup manusia, tetapi juga sudah mencapai taraf yang sedemikian mengancam kehidupan umat manusia sendiri. ${ }^{1}$ Kerusakan alam adalah bentuk kegagalam manusia dalam mengelola dan bertanggung jawab untuk membuat bumi menjadi tempat yang layak huni dan mendukung kehidupan mansuia. Di dalam topik mengenai kerusakan lingkungan, banyak diskusi dan pembicaraan yang mengkategorikan permasalahan kerusakan lingkungan yang paling mendapatkan perhatian serius, yaitu: pemanasan global (global warming), perusakan hutan secara massal berikut dengan erosi tanah, dan juga permasalahan polusi.

Dari pihak umat Kristiani misalnya, banyak yang menilai orang beriman terkesan abai terhadap permasalahan ekologi, hal ini nampak misalnya dalam pesan Paus Yohanes Paulus II di hari Perdamaian Sedunia dengan mengungkapkan:

"Perdamaian dunia bisa saja terancam bukan hanya oleh perlombaan senjata, pelbagai konflik, dan terus berlangsungnya ketidakadilan antar bangsa, melainkan juga disebabkan oleh kurangnya penghargaan atas alam. Kesadaran baru ekologis jangan sampai disepelekan oleh gereja, melainkan gereja-gereja harus inisiatif mengembangkan program konkret dalam upaya penyelamatan lingkungan."2

Pesan ini tentu saja sebagai pengingat bagi setiap gereja dan orang beriman untuk bertindak sebagai ciptaan Allah yang mampu berperan menjaga keutuhan lingkungan hidup dan tentu saja supaya orang beriman memiliki pemahaman yang utuh dan benar sehingga alam tidak dirusak dalam oleh keegoisan dan ketidakpedulian manusia.

\footnotetext{
${ }^{1}$ Michael Northcott, The Environment and Christian Ethics (Cambridge: Cambridge University Press, 1996), 2.

${ }^{2}$ A. Sunarko and Eddy Kristiyanto, Menyapa Bumi Menyembah Hyang Ilahi: Tinjauan Teologis Atas Lingkungan Hidup (Yogyakarta: Kanisius, 2012), 53.
} 
Keprihatinan serupa juga diungkapkan oleh seorang sejarahwan bernama Lynn White yang menyatakan bahwa sebenarnya ada tanggung jawab dan peran dari orang Kristen dalam permasalahan kerusakan ekologi, karena selama ini orang Kristen dianggap secara tidak seimbang telah mengajarkan tentang doktrin manusia sebagai penguasa atas bumi dan ciptaan lainnya (bdk. Kej. 1:27-28) yang tentu saja hal ini dipercaya telah menimbulkan eksploitasi atas alam secara berlebihan. ${ }^{3}$ Tentu saja bagian yang dikritik oleh Lynn White ini menjadi benar jika gereja dan para pemimpin Kristen tidak peduli terhadap permasalahan ekologi, yang tentu saja berdampak pada setiap pengajaran yang dibuat bersifat antroposentris terhadap alam.

Telaumbanua juga menyetujui bahwa gereja sendiri masih belum maksimal dalam menangani ataupun berkontribusi langsung dalam menangani kerusakan lingkungan hidup. Hal ini dapat ditilik dari khotbah-khotbah gereja ataupun materimateri pengajaran gereja yang sangat jarang sekali membahas mengenai ekologi, gereja juga jarang sekali menegur gaya hidup manusia yang berkontribusi terhadap pengrusakan lingkungan, dan ditambah lagi gereja-gereja perkotaan yang besar bisa saja terkadang bersikap tak peduli dengan permasalahan lingkungan global, dengan misalnya tidak menghemat pemakaian listrik, pemakaian AC berlebihan, tidak melakukan penghijauan di lingkungan gereja, dan masih banyak lagi. ${ }^{4}$ Oleh sebab itu, dalam hal ini dirasa sangat perlu untuk gereja mampu mengkondisikan diri dan berbenah dalam perannya untuk menjadi pembawa damai bagi dunia dengan terlibat dalam pelestarian lingkungan.

Dari fakta - fakta diatas, maka pertanyaan yang timbul adalah adakah sumbangan teologi Kristen sebagai landasan teologis terhadap upaya untuk memulihkan alam yang terlanjur rusak dan untuk mencegah pengrusakan yang semakin parah? Oleh sebab itu diperlukan kembali pemahaman yang benar dan terbuka mengenai korelasi antara teologi dengan ekologi. Sebab dalam kehadirannya di dunia, manusia tidak hanya mempunyai tanggung jawab kepada Allah, namun juga mempunyai tanggung jawab dalam memelihara dan mengembangkan kehidupan bersama ciptaan lain yang tidak bisa diabaikan.

Dalam hal ini peneliti mengupayakan untuk meneliti kitab Kejadian, karena dalam kitab Kejadian terdapat idetitas manusia sebagai rekan sekerja Allah sekaligus sebagai citra Allah. Pada kitab Kejadian pasal 2 diceritakan bahwa Taman Eden disediakan oleh Allah untuk manusia dengan kepentingan yang mulia, yaitu untuk diusahakan oleh manusia. Tetapi bukan berarti mengusahakan dengan sembarangan, namun perlu diingat bahwa masih terdapat kepentingan lainnya, yaitu untuk didiami oleh seluruh ciptaan Allah pada waktu itu secara bersama-sama. Itulah sebabnya diberikan pula tugas dari Allah kepada manusia pada waktu itu untuk juga memelihara

\footnotetext{
${ }^{3}$ Lynn White, The Historical Roots of Our Ecological Crisis (New York: Harper and Row, 1994), 78.

${ }^{4}$ S Telaumbanua, 'Pak Gereja Dalam Konteks Lingkungan Hidup Suatu Refleksi Terhadap Markus 16:15', Jurnal Shanan, 4.1 (2020), 41-56, http://ejournal.uki.ac.id/index.php/shan/article/view/1767.
} 
Taman Eden. Hal inilah yang mendorong kajian penelitian mengenai tafsir terhadap Kejadian 2:15 khususnya terhadap kata kerja mengusahakan dan memelihara Taman Eden sebagai konstruksi pemahaman bagi orang percaya mengenai tanggung jawabnya terhadap lingkungan.

\section{Metode Penelitian}

Metode yang dipakai dalam makalah ini adalah analisis teks dengan pendekatan eksegesa pada teks Kejadian 2:15, khususnya dibatasi pada kata kerja mengusahakan dan memelihara Taman Eden. Peneliti melakukan analisis terhadap kata kerja tesebut, kemudian melengkapinya dengan sebuah tafsiran yang didapat dari berbagai sumber yang relevan. Dari hasil eksegesa terhadap kata kerja mengusahakan dan memelihara Taman Eden akan ditarik temuan teologis sebagai konstruksi untuk memberikan beberapa prinsip penting mengenai pelayanan dan tanggung jawab orang percaya kepada lingkungan.

Dipilihnya teks Kejadian 2:15 hal ini karena menunjukkan taman Eden merupakan representasi dari keseluruhan bumi pada saat itu, tempat dimana manusia ditempatkan Allah untuk hidup dan berkarya mengusahakan taman tersebut sebelum kejatuhan manusia dalam dosa. ${ }^{5}$ Tetapi bukan berarti mengusahakan dengan tidak bertanggung jawab, namun manusia juga dibebankan tanggung jawab pemeliharaan atas taman tersebut. Pemahaman ini sangat penting untuk dimiliki dan akan dibahas dalam bagian selanjutnya untuk memberikan penegasan bahwa manusia bukan sekadar pengguna apalagi penguasa taman tersebut, melainkan sebagai penatalayan dan rekan sekerja Allah yang bertanggung jawab untuk mewujudkan keadaan taman Eden tersebut lebih baik lagi.

\section{Hasil dan Pembahasan}

\section{Analisa Kata Mengusahakan dan Memelihara Taman Eden dalam Kejadian 2:15}

Sebelum membahas secara detail mengenai kata kerja mengusahakan dan memelihara pada Kejadian 2:15, maka dirasa penting untuk pertama kali memberikan ulasan mengenai Taman Eden yang menjadi lokasi yang dibicarakan dalam teks Kejadian 2:15. Kata עִ עִרן ( Indonesia tetap diterjemahkan sebagai Eden. Para penafsir Septuaginta (LXX) mengungkapkan sebuah keterangan bahwa bagi seorang berkebangsaan Yunani, nama עִרִן (ëden) yang diterjemahkan menjadi $\pi \alpha \rho \alpha \delta \varepsilon 1 \sigma o \varsigma$ (paradeisos) dalam LXX sebenarnya mengarah kepada sebuah pengerian "sesuatu yag menyenangkan hati" atau "kesenangan hati". Dan kata $\pi \alpha \rho \alpha \delta \varepsilon \imath \sigma o s$ (paradeisos) dalam LXX ini diduga merupakan

\footnotetext{
${ }^{5}$ Sonny Eli Zaluchu, Biblical Theology: Pembahasan Metodologi Dan Pendekatan Biblika Dalam Membangun Teologi PL Dan PB Yang Alkitabiah (Semarang: Golden Gate Publishing, 2017), 98.
} 
sebuah alih bahasa dari bahasa Avesta (Persia kuno) yaitu pairidaeza, yang maknanya adalah "sesuatu yang dipagari", dan kemudian pada perkembangan berikutnya, mendapat perluasan makna sebagai "halaman atau kebun yang menyukakan." Bahkan nantinya dari pemakaian istilah pairidaeza inilah lambat laun muncul kosa kata dalam bahasa Inggris, yaitu "paradise" untuk menyebut istilah Taman Firdaus atau Taman Eden.

Narasi dalam Kejadian pasal 2 menjelaskan bahwa Taman Eden merupakan adalah sebuah lokasi yang diberkati dengan keindahan dan sesuatu yang menyenangkan yang sebenarnya disiapkan dan dibuat oleh Allah sendiri sebagai habitat manusia pertama kala itu. Gambaran yang menyenangkan dari Taman Eden sebenarnya terlihat dari cara Musa mendeskripsikan kondisi taman tersebut yang terdapat banyak tumbuhan dan pohon, baik yang indah-indah maupun aneka jenis tanaman yang menghasilkan buah-buahan sebagai makanan manusia (bdk. Kej. 2:16), termasuk pohon kehidupan juga terdapat dalam taman ini (Kej. 2:9). Lebih jauh dijelaskan, taman ini adalah suatu tempat yang subur, karena dikelililingi oleh empat sungai besar yang bertujuan sebagai pengairan untuk membasahi taman Eden (Kej. 2:10). Rupanya kabut saja (bdk Kej. 2:6) tidak cukup untuk membuat pohon-pohon dalam taman itu menjadi hidup dan subur, tetapi membutuhkan suplai air yang cukup banyak dari empat sungai besar supaya pohon-pohon tersebut menghasilkan daun dan buah. Jadi disini dapat dilihat perhatian Allah yang sangat besar terhadap lingkungan sebagai habitat manusia. ${ }^{6}$ Taman Eden juga dilengkapi oleh Allah dengan sumber daya alam yang penuh dengan batu mulia, baik itu batu permata krisopras, emas, dan damar bedolah (bdk. Kej. 2:1011).

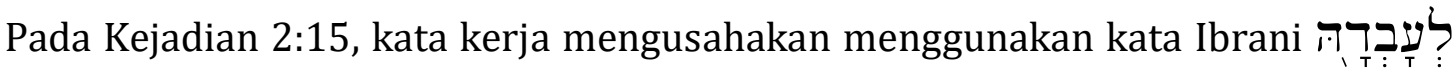

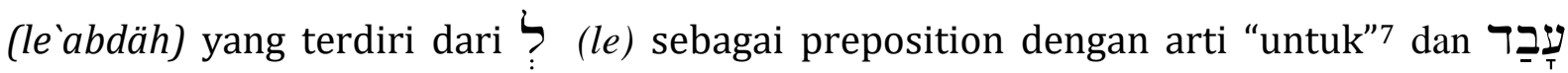
(abad) yang merupakan kata kerja qal infinitive construct 3rd person feminine singular yang secara umum memiliki arti mengerjakan atau mengusahakan. ${ }^{8}$ Sehingga arti

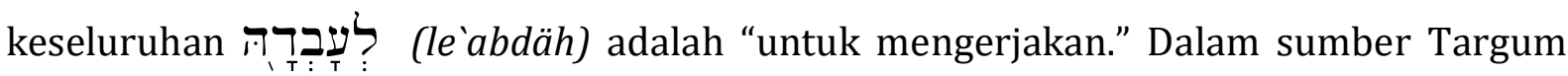

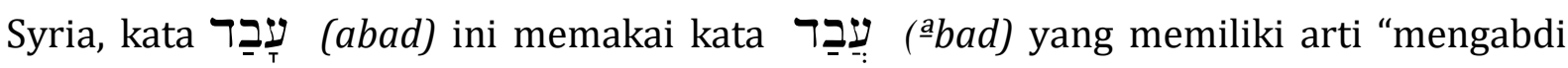
sebagai hamba". Sedangkan sumber dari Arab kuno memakai kata deriv yang berarti "pemujaan atau kepatuhan pada Tuhan."9

Kata עָער ('âbad) pertama kali muncul dalam Alkitab, yakni dalam Kejadian 2:5 untuk menceritakan keadaan pasca Tuhan selesai menciptakan langit dan bumi, yaitu dikisahkan bahwa di bumi belum ada semak dan tumbuhan di padang karena: belum

\footnotetext{
${ }^{6}$ E.A Speiser, The Rivers of Paradise (Festschrift: Johannes Friedrich, 1959), 475.

${ }^{7}$ T.G.R. Boeker, Bahasa Ibrani Jilid I (Batu: STT “I3", 1992), p. 71.

8 John Joseph Owens, Analitical Key to the Old Testament Vol I (Grand Rapids: Baker Book House), 8.

${ }^{9}$ Francis Brown, The New Brown-Driver-Briggs-Genesius Hebrew English Lexicon (Massachusetts: Hendrickson Publishers, 2001), 713.
} 


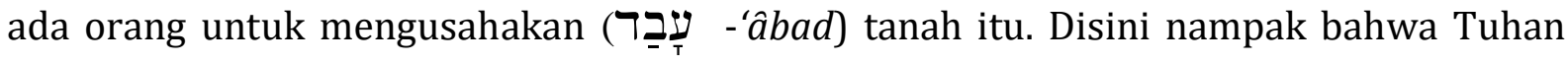
menciptakan bumi dan isinya sebagai tempat manusia berdayaguna dan mengusahakan sesuatu. Allah telah bekerja dengan menciptakan bumi dan menyediakan Taman Eden, maka Ia pun menginginkan manusia yang telah diciptakan sesuai citra-Nya juga menjadi rekan sekerja-Nya. Banks menyatakan bahwa:

"Manusia merupakan satu-satunya ciptaan yang memiliki keiistimewaan sebagai Imago Dei, dan perlu diketahui bahwa natur yang dimiliki oleh Allah adalah bahwa Dia bukanlah Allah yang diam tanpa karya, namun Ia adalah Allah yang bekerja dan terus aktif berkarya sampai saat ini. Oleh sebab itu, harus dipahami bahwa jika Allah adalah sosok yang aktif bekerja, maka manusia pun sebagai mahluk ciptaan Allah yang mulia juga harus berkarya dan bekerja."10

Oleh sebab itu, inilah alasan mengapa muncul kembali kata עָ עָברד ('âbad) dalam Kejadian 2:15 yang menyiratkan Tuhan ingin manusia bekerja dan mengusahakan Taman Eden.

Menurut Donald A. Hagner, kata עָרבד ('âbad) dalam kemunculannya dalam Perjanjian Lama lebih banyak dipakai dalam pengertian melakukan suatu pekerjaan yang berhubungan dengan melayani Tuhan. ${ }^{11}$ Bahkan dalam konteks keimaman dalam Perjanjian Lama, kata עָָרבר ('âbad) ini selalu dipakai dalam hal yang berhubungan dengan pekerjaan para Imam atau yang berhubungan dengan pekerjaan di Kemah עיעבר ('âbad) selalu dipakai untuk menjelaskan tugas atau pekerjaan yang diperintahkan oleh Allah kepada orang Israel, khususnya orang Lewi ketika mereka hendak mengurus perabotan di dalam Kemah Suci.

Dalam kemunculannya di Perjanjian Lama, kata dasar עִבַר ('âbad) juga sering diterjemahkan "beribadah", seperti kemunculannya dalam Keluaran 3:12; 7:16, dan Mazmur 22:31, kata beribadah dalam ayat tersebut memang memakai kata Ibrani עָבָר ('âbad). Bahkan dalam Septuaginta, kata mengusahakan di Kejadian 2:15 ini memakai

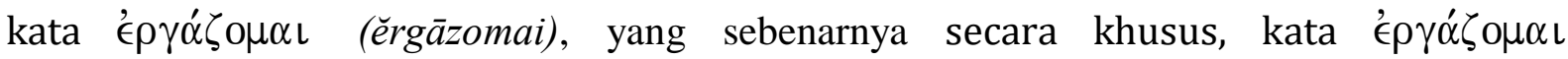
(ĕrgāzomai) ini juga merupakan kata kerja yang dipakai bagi mereka yang melakukan

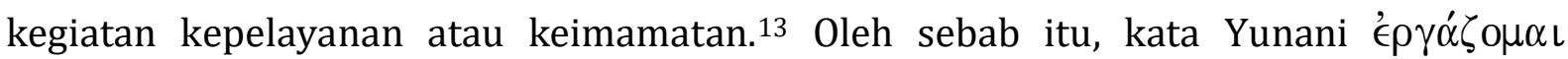
(ěrgāzomai) ini juga dipakai oleh Rasul Paulus untuk menunjukkan suatu pekerjaan pelayanan yang berhubungan dengan hal-hal rohani atau ibadah (bdk. 1 Kor. 9:13; 16:10).

\footnotetext{
${ }^{10}$ Robert J. Banks, God the Worker: Journeys into the Mind, Heart and Imagination of God (Valley Forge: Judson, 1994), 129.

${ }^{11}$ Christopher Barth, Theologia Perjanjian Lama 3 (Jakarta: BPK Gunung Mulia, 2005), 96.

12 Donald A. Hagner, World Biblical Commentary Vol I (Texas: Word Books Publishers, 2005), 67.

${ }^{13}$ Timothy Friberg, Analitical Lexicon of the Greek New Testament (Trafford Publishing), 313.
} 
Maka dari uraian di atas, kata "mengusahakan" - עلָحַר ('âbad) harus dipahami dalam pengertian: segenap tindakan atau pekerjaan manusia dalam mendayagunakan pikiran, tenaga, kemampuan serta ketrampilannya terhadap suatu objek yang telah dimandatkan oleh Allah, sehingga manusia harus bertanggung jawab kepada Allah sebagai wujud pelayanan dan ibadah manusia kepada-Nya. Marie-Dominique Chenu, seorang teolog yang memberi perhatian terhadap masalah ekologi mengatakan bahwa:

"Dengan mengusahakan Taman Eden, maka manusia membuktikan dirinya bertanggung jawab terhadap Allah, karena mengusahakan Taman Eden merupakan mandat dan perintah Allah. Manusia adalah seorang pekerja, maka bumi ini diciptakan Tuhan tidak selesai begitu saja, namun tetap harus dilanjutkan oleh manusia. Manusia yang telah menerima perintah dari Allah untuk mengusahakan bumi, tentu saja ini tidak berarti Allah tidak dapat melanjutkan atau menyelesaikan karya-Nya di bumi. Namun, pada titik ini Allah ingin melibatkan manusia sebagai rekan kerja-Nya untuk bersama-sama bekerja mengelola hasil karya Allah. Sebab jika Allah tidak memberi mandat manusia untuk bekerja, maka secara tidak langsung Allah telah melenyapkan natur manusia itu sendiri. Perintah dari Allah untuk "mengusahakan" ini sebenarnya paralel dengan mandat prokreasi yang Allah berikan kepada manusia (bdk. Kej 1:28)."14

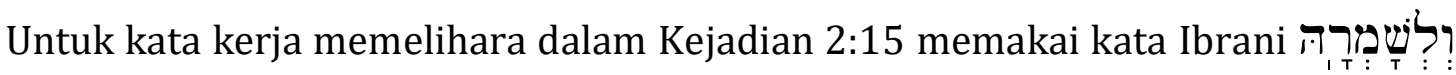
(welesamräh) yang terdiri dari ? (we) sebagai conjunction dengan arti "dan",15 kemudian? (le) sebagai preposition dengan arti "untuk"16 dan juga שֵַָׁ (shamar) yang merupakan kata kerja qal infinitive construct 3rd person feminine tunggal dengan

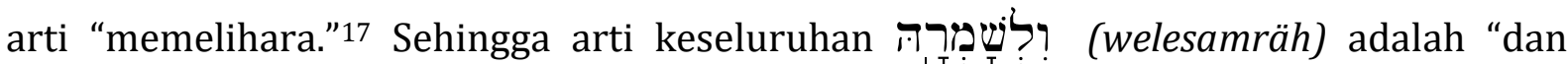

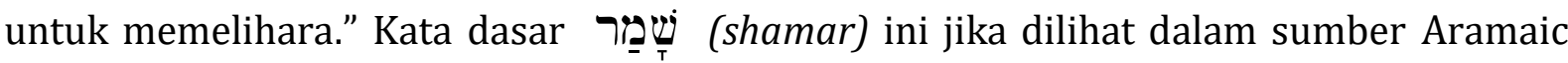

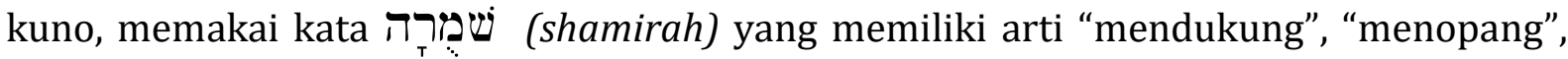
"melindungi". Sedangkan Sumber dari Arab kuno memakai kata Samara yang berarti "memperhatikan dengan sungguh-sungguh".18

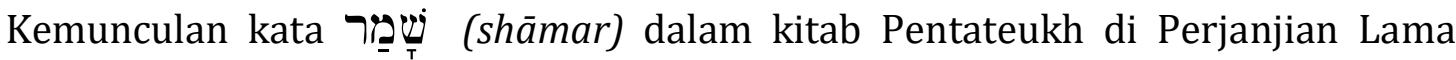
bukan sekedar berarti "memelihara" atau "melindungi", namun memiliki makna lebih

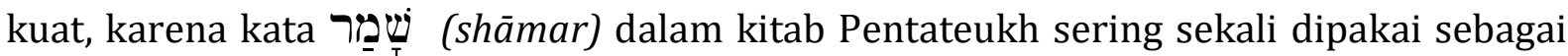
kata kerja yang berhubungan dengan tanggung jawab umat Allah terhadap hukum dan

\footnotetext{
${ }^{14}$ M. D. Chenu, The Theology of Work: An Exploration (Chicago: Regnery, 1966), 4.

${ }^{15}$ Boeker, 48.

${ }^{16}$ Boeker, 71.

${ }^{17}$ Owens, 8.

${ }^{18}$ H.W.F Gesenius, Gesenius' Hebrew-Chalde Lexicon to the Old Testament (Grand Rapids: Michigan, 2000), 837.
} 
ketetapan Allah yang senantiasa harus diingat, dipelihara dan dilakukan dengan setia, bahkan sampai turun temurun. ${ }^{19}$ Sehingga tidak heran, sering sekali kita jumpai sebuah perintah dari Allah dalam Perjanjian Lama selalu memakai kata kerja: שׁَِ (shāmar), yang menyiratkan bahwa Allah ingin segenap yang diperintahkan oleh-Nya harus benarbenar diperhatikan dan dipelihara turun temurun oleh umat-Nya, seperti yang terdapat dalam Keluaran 12:25; 34:11, dan Imamat 26:2 ketika Allah mengatakan bahwa hukum

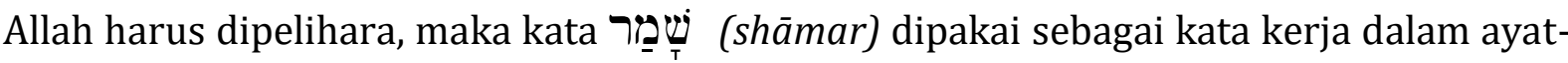
ayat tersebut.

Jika ditinjau secara umum, sebenarnya pemakaian kata "memelihara" - שָׁפַָר (shāmar) sangat berkaitan dengan tugas seorang gembala, yang bukan hanya bertugas menjaga kawanan domba, namun sang gembala tersebut juga harus mengawasi, memelihara, melindungi, dan peduli terhadap kelangsungan hidup domba-dombanya, yang merupakan objek yang harus dipelihara dengan penuh tanggung jawab. ${ }^{20}$ Kata Shamar yang berarti "memelihara" sebenarnya dalam tata bahasa Ibrani mempunyai kemiripan kata dengan kata Ibrani shamiyr yang memiliki arti 'duri'. Tentu saja kemiripan kata ini dapat memiliki keterkaitan karena untuk menjaga domba dari serangan atau ancaman binatang buas, seorang gembala biasanya menggunakan kawat atau tanaman duri untuk memagari dan melindungi kawanan dombanya.

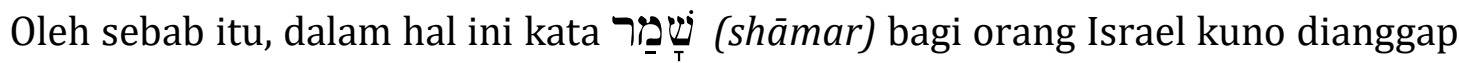
sebagai kata kerja yang menunjukkan tindakan kasih Allah sebagai seorang Gembala bagi umat-Nya yang senantiasa memelihara, melindungi, dan memberikan perhatian

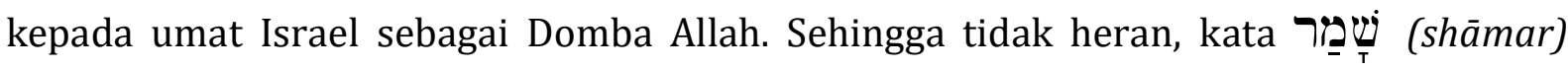
dapat ditemukan dalam awal ucapan berkat seorang Imam pada Bilangan 6:24: "TUHAN

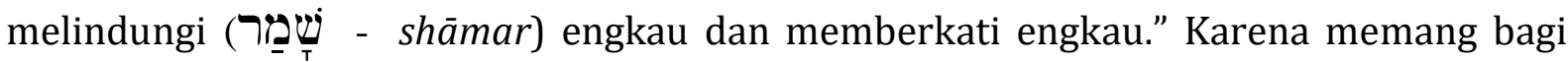
umat Israel, Allah adalah Pribadi yang memelihara dan melindungi seperti seorang Gembala. ${ }^{21}$

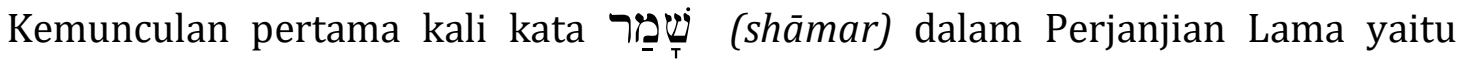
memang ada dalam Kejadian 2:15 ini, yaitu saat Adam diperintahkan Allah untuk memelihara Taman Eden. Hal ini juga disebutkan dalam Kejadian 4:9, dimana Kain

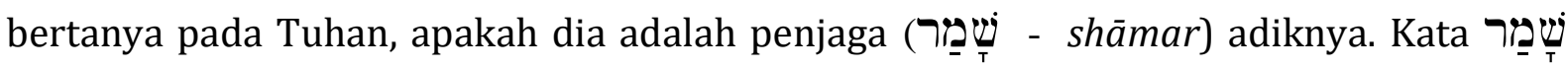
(shāmar) yang muncul dalam bagian awal Perjanjian Lama ini memiliki pengertian:

\footnotetext{
${ }^{19}$ Hagner, 67.

${ }^{20}$ David J. Evans, Biblical Holism and Agriculture: Cultivating Our Roots (California: William Carey Publishers, 2008), 83.

${ }^{21}$ Evans, 83.
} 
memelihara, melindungi, mengawasi, peduli, dan menjamin keamanan dari suatu objek. $^{22}$

Dalam Septuaginta, kata memelihara memakai kata Yunani $\phi \cup \lambda \alpha ́ \sigma \sigma \omega$ (phulāsso), yang secara umum biasanya diterjemahkan "menjaga" ataupun "memelihara". ${ }^{23}$ Secara khusus, sebenarnya kata $\phi \cup \lambda \alpha ́ \sigma \sigma \omega$ (phulāsso) mulanya sering digunakan dalam istilah militer yang menunjukkan kegiatan di pos penjagaan pada zaman Romawi kuno, dimana seorang tentara harus peduli dan bertanggung jawab untuk melindungi markas atau benteng pusat yang sedang ia jaga. ${ }^{24}$ Dan dalam perkembangannya kemudian, kata $\phi \cup \lambda \alpha ́ \sigma \sigma \omega$ (phulāsso) merujuk secara umum pada tindakan manusia yang secara dan sadar dan bertanggung jawab untuk melaksanakan tindakan kasih dan kepedulian untuk menjaga, merawat, dan memelihara sesuatu yang ditugaskan kepadanya. Dalam

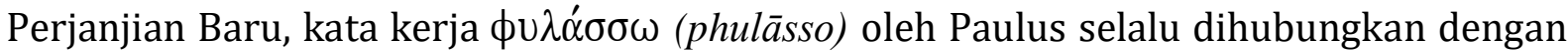
Hukum Taurat, seperti contohnya dalam Kisah Para Rasul 21:24 dan Galatia 6:13, Paulus berulangkali menyampaikan kepada pembaca surat-Nya hukum Taurat yang dipelihara

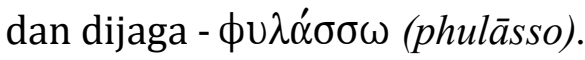

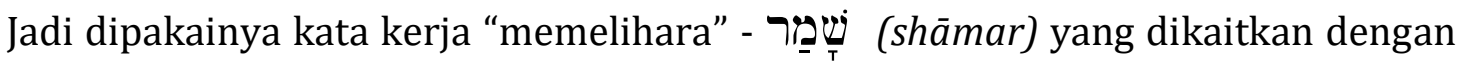
hukum, perjanjian dan perintah dari Allah, sesungguhnya hal ini menunjukkan bahwa Allah ingin supaya manusia sebagai ciptaan yang segambar dan serupa dengan Allah dapat menyatakan perhatiannya dan berpegang dengan sungguh-sungguh terhadap hukum dan perjanjian-Nya. ${ }^{25}$ Sebab ketaatan terhadap hukum-hukum Allah itu bukan hanya masalah teori saja atau ketaatan ala kadarnya yang asal mengerti, namun harus benar-benar dipelihara dan dijaga kelangsungannya bahkan sampai turun temurun, supaya hukum dan perintah Allah dapat diketahui dari generas ke generasi.

Dari uraian diatas dapat disimpulkan, bahwa sejak dari kemunculan pertama kali

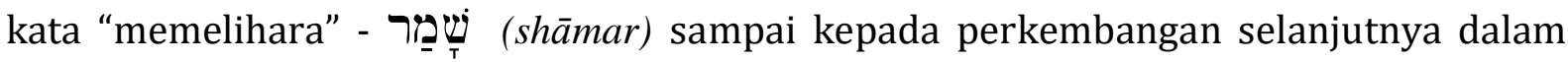
Perjanjian Lama, maka kata "memelihara" - שَِّ (shāmar) harus dipahami dalam pengertian: memelihara, melindungi, mengawasi, memperhatikan, dan menjamin kelangsungan suatu objek yang Allah telah mandatkan kepada manusia dengan sungguh-sungguh.

\section{Temuan Teologis}

\footnotetext{
${ }^{22}$ Matthew Myer Boulton, God Against Religion: Rethinking Christian Theology through Worship (Grand Rapids: Michigan, 2008), 68.

${ }^{23}$ William D. Mounce, The Analytical Lexicon to the Greek New Testament (Grand Rapids: Michigan, 2000), 476.

${ }^{24}$ Kay Arthur, The New How to Study Your Bible: Discover the Life-Changing Approach to God (Oregon: Harvest House Publishers, 1994), 189.

${ }^{25}$ Boulton, 69.
} 
Dari hasil analisa kata mengenai mengusahakan dan memelihara Taman Eden pada Kejadian 2:15 yang telah dilakukan di atas, maka didapatkan dua temuan teologis yang akan diuraikan sebagai berikut:

Mengusahakan dan Memelihara Taman Eden sebagai Bentuk Pelayanan kepada Allah melalui Lingkungan

Dalam analisa kata yang telah dilakukan di bagian sebelumnya, didapati bahwa sesungguhnya tindakan manusia untuk mengerjakan dan mengusahakan Taman Eden, pada dasarnya adalah salah satu bentuk pelayanan dan ibadah manusia kepada Allah

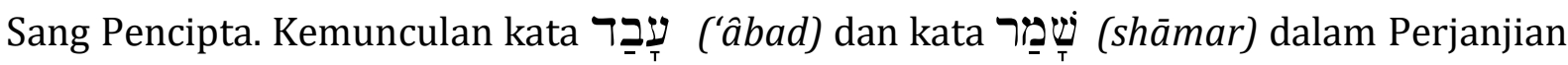
Lama sering sekali dihubungkan dengan tindakan melayani Tuhan dan ibadah manusia kepada Tuhan. Konsep pelayanan ini sesungguhnya menunjukkan bahwa kedudukan manusia dalam alam ini bukanlah raja yang sewenang-wenang atas alam, tetapi ia adalah hamba yang menjadi mitra Allah untuk mengerjakan mandat mengusahakan dan memelihara lingkungan. Manusia bukanlah pemilik lingkungan, melainkan manusia hanyalah pengelola yang diberi kepercayaan oleh Allah yang harus dipertanggung jawabkan kembali kepada Allah.

Hal yang menarik yang dapat dilihat dari Kejadian 2:15 adalah inisiatif dari Allah yang menyediakan Taman Eden sebagai habitat manusia pertama padawaktu itu. Narasi Kejadian 1 memang mengisahkan bahwa Allah telah menciptakan dan meyiapkan bumi dengan kondisi yang sangat baik dan siap sedia untuk dihuni oleh manusia. Bahkan jika dipikirkan kalaupun Allah tidak menyediakan Taman Eden, sebenarnya bumi masih cukup luas, cocok, dan layak untuk didiami manusia. Namun dapat dilihat bahwa Allah masih ingin memberikan manusia perhatian yang khusus dan dengan tujuan yang mulia. Allah menyiapkan dan membuat sebuah taman sebagai habitat manusia yang sangat indah dan menyenangkan yang melebihi keindahan bumi pada umumnya (Kej. 2:8-15). Apa yang telah dilakukan oleh Allah untuk kepentingan manusia, menunjukkan betapa Allah sangat mengasihi dan peduli kepada manusia.

Ketika Allah memberikan mandat untuk mengusahakan dan memelihara Taman Eden kepada manusia, juga seharusnya membuat manusia berpikir dan sadar, bahwa kedudukannya di Taman Eden, bukanlah sebagai pemilik, penguasa, maupun pendominasi alam, karena Allah adalah Sang Pemilik. Manusia hanya sebagai mitra kerja Allah untuk mengusahakan dan memelihara lingkungan dengan penuh kasih, kerelaan, kesadaran dan pelayanan sebagai bentuk pengabdian dan ibadah kepada Tuhan. ${ }^{26}$ Manusia harus mengerahkan daya upaya (baik itu tindakan, kreativitas, inovasi, pemikiran, penemuan, dan kewirausahaan) untuk mengusahakan dan memelihara

\footnotetext{
${ }^{26}$ Alan Richardson, The Biblical Doctrine of Work (London: SCM Press, 1994), 46.
} 
sesuatu yang telah dimandatkan oleh Tuhan. Inilah yang disebut dalam religiusitas dalam pekerjaan.

Salah satu pernyataan yang menjelaskan kaitan antara kerja dan religiusitas adalah ungkapan yang diberikan oleh Santo Benediktus yang dikenal dengan istilah berdoa dan bekerja (Ora et Labora). Bimo Setyo Utomo mengatakan bahwa hal ini menunjukkan bahwa umat Allah dituntut untuk menyeimbangkan dan tidak memisahkan antara religiusitas dan pekerjaan. Dengan konsep yang benar tentang pekerjaan, maka orang Kristen harusnya dapat meletakkan pekerjaannya sebagai sarana mewujudkan kemuliaan Allah yang lebih besar dan agung (Ad Majorem Dei Gloriam).27 Jika sudah demikian, dapat dipastikan bahwa etos kerja dan tanggung jawab dalam bekerja akan terbangun dengan positif, termasuk dalam bekerja untuk menguayakan dan melestarikan alam.

Manusia sebagai citra Allah memiliki sifat-sifat yang luhur seperti: sabar penuh kasih, pengendalian diri, memiliki pikiran, perasaan, kehendak, serta pengetahuan yang dapat diselaraskan dengan kebenaran dari Allah. Maka jika Allah memiliki sifat yang luhur, yakni ketika menciptakan sesuatu, Ia juga akan memelihara apa yang sudah diciptakan-Nya, maka demikian juga dengan manusia, ketika manusia diberi mandat untuk mengusahakan dan memelihara, maka manusia harus memiliki dasar kasih dan taat melayani dalam melakukan mandat tersebut. ${ }^{28}$ Segala bentuk kreativitas, inovasi, pemikiran, penemuan, kewirausahaan, pengelolaan, dan pendayagunaan yang dilakukan manusia terhadap suatu objek, termasuk lingkungan harus diimbangi pula oleh tindakan kepedulian, pemeliharaan dan perawatan.

Hal di atas memang bukanlah hal yang mudah dan otomatis untuk dapat dilakukan, karena dalam tindakan mengusahakan dan memelihara lingkungan dibutuhkan sikap hati untuk melayani dengan penuh komitmen, konsistensi serta kedisiplinan kuat dari manusia, namun biarlah motivasi kasih dan ketulusan menjadi dasar dan tujuan manusia dalam melakukan mandat mengusahakan dan memelihara. Tentu saja dasar hubungan seimbang untuk mengusahakan dan memelihara adalah Kasih dan Anugerah Allah. Oleh karena itu, teologi Alkitab bukanlah teologi antroposentrisme ataupun ekosentrime, melainkan teologi teosentrisme yang memandang segala sesuatu berpusat pada Allah, yaitu Allah yang menurut Alkitab adalah pencipta bumi ini yang menganugerahkan keindahan dan kekayaan bumi ini kepada manusia untuk dikelola secara bertanggung jawab. ${ }^{29}$

Jadi mengusahakan dan memelihara lingkungan menurut konsep Kejadian 2:15 adalah manusia bisa mengambil dan memanfaatkan serta mengembangkan lingkungan

\footnotetext{
${ }^{27}$ Bimo Setyo Utomo, ‘Konsep Bekerja Sebagai Ad Majorem Dei Gloriam : Sebuah Upaya Pemenuhan Sacred Calling', Excelsis Deo: Jurnal Teologi, Misiologi, Dan Pendidikan, 3.2 (2019), 1-12, https://ejournal.sttexcelsius.ac.id/index.php/excelsisdeo/article/view/12.

${ }^{28}$ J.L.Abineno, Manusia Dan Sesamanya Di Dalam Dunia (Jakarta: BPK Gunung Mulia, 2003), 46.

${ }^{29}$ John Stott, Issues Facing Christian Today (London: Marshall Morgan and Scott, 1984), 202.
} 
hidup dengan tetap memperhatikan, menghargai, dan sedapat mungkin menyesuaikan diri dengan irama ekosistem. Itulah inti mengusahakan dan memelihara sebagai bentuk pelayanan yang memang bertujuan supaya orang percaya memiliki pemahaman untuk memanfaatkan dan menggunakan sumber daya alam secara proporsional dan dapat dipertanggung jawabkan kepada Allah sesuai norma kebenaran.

\section{Mengusahakan dan Memelihara Taman Eden sebagai Bentuk Tanggung Jawab Manusia} kepada Lingkungan

Gagasan mengenai manusia sebagai pengurus (steward) yang diberikan mandat oleh Allah untuk bertanggung jawab atas Taman Eden yang harus dikelola dan dipelihara, tentu saja hal ini didukung oleh konsep tentang manusia sebagai gambar dan rupa Allah. Penegasan bahwa kaitan antara manusia sebagai gambaran Allah dan kuasa yang diberi kepadanya menyiratkan bahwa kuasa itu harus mencerminkan kuasa Allah, Sang Pencipta dan Pemelihara. Maka kuasa atas binatang itu mesti merupakan pemerintahan damai, tanpa hak atas hidup dan mati. Penaklukan bumi pun tidak melulu dimengerti sebagai penundukan, melainkan sebagai perintah untuk mengolah tanah guna memperoleh makanan, dimana manusia bersama binatang hidup dan berkembang dari apa yang dihasilkan oleh bumi. ${ }^{30}$ Sebagai wakil Allah tentu manusia diberikan tugas untuk menjalankan mandat Allah atas bumi, khususnya terhadap lingkungan dengan penuh perhatian dan tanggung jawab yang sama seperti yang Allah telah teladankan ketika Ia bekerja. ${ }^{31}$

Taman Eden merupakan representasi dari keseluruhan bumi, tempat dimana manusia ditempatkan Allah, dimana taman tersebut diciptakan untuk tujuan yang mulia, yaitu selain untuk didiami manusia, namu juga untuk diusahakan oleh manusia. Namun hal ini tidak berarti mengusahakan dengan serampangan dan tak bertanggung jawab, karena terdapat hal luur lainnya yakni menjadi rumah bersama bagi seluruh ciptaan (bdk. Kej 2:9,19). Itulah sebabnya dalam konteks pembahasan kali ini, dapat dilihat bahwa manusia juga dimandatkan pemeliharaan atas Taman Eden sebagai representasi habitat manusia (Kej. 2:15). Dalam hal ini kekristenan seyogianya melihat alam tidak melulu sebagai fakta biologis, tetapi alam juga harus dipandang sebagai cerminan sang Pencipta. Hal ini berarti bahwa alam itu sebagai bayang-bayang Allah, sehingga manusia harus terus menghargai alam sebagai karya Allah dan karena itu harus memperlakukannya sebagai milik Allah yang patut dihargai, dihormati, dan diperlakukan dengan penuh tanggung jawab kepada Allah demi kebaikan manusia itu sendiri. ${ }^{32}$

\footnotetext{
${ }^{30}$ Hannes Steck, World and Enviromnent (Nashville: Abingdon, 1980), 102.

${ }^{31}$ Lester Brown, Tantangan Masalah Lingkungan (Jakarta: Yayasan Obor, 1999), 76.

${ }^{32}$ Marianus Patora, 'Peranan Kekristenan Dalam Menghadapi Masalah Ekologi', Jurnal Teruna Bhakti, 1.2 (2019), 117-27, http://e-journal.stakterunabhakti.ac.id/index.php/teruna/article/view/19.
} 
Pemahaman akan tanggung jawab ini sangat penting untuk dimiliki khususnya bagi orang-orang percaya, karena mandat "mengusahakan" dan "memelihara" sudah sangat jelas menegaskan bahwa manusia bukan sekadar pengguna apalagi pendominasi alam melainkan sebagai penatalayan yang bertanggung jawab (responsible stewardship). Dan ini tentu saja sangat bertolak belakang dengan pandangan materialistik. ${ }^{33}$ Perlu juga dipahami bahwa konsep stewardship (penatalayan) merupakan pertanggungjawaban yang tidak saja secara individu tetapi juga secara bersama. Secara individu, dimulai dengan panggilan Allah, dan diberi tanggung jawab. Bersamaan dengan tanggungjawab individu tersebut, manusia juga merupakan steward (pengurus) yang bekerjasama dengan orang lain dalam mengusahakan dan memelihara lingkungan.

Dalam hal ini Remikatu mnengungkapkan bahwa gereja memiliki peran dalam upaya pemeliharaan lingkungan hidup yang terletak pada tugasnya sebagai imam, raja dan nabi. Pertama, gereja sebagai imam merupakan peran sebagai wakil atas sesama dan ciptaan yang lain di hadapan Allah dan juga merupakan wakil Allah dalam membawa kedamaian dan kesejahteraan bagi mahkluk lainnya di bumi. Kedua, tugas gereja sebagai nabi merupakan tugas yang mengoreksi dan memperbaiki keadaankeadaan yang rusak karena sikap manusia yang destruktif karena praktek-praktek ketidakadilan akibat praktek eksploitasi alam yang sewenang wenang. Gereja dipanggil untuk menyuarakan kebenaran atas ketidakadilan yang terjadi akibat keserakahan manusia yang menyebabkan kerusakan lingkungan. Ketiga, tugas gereja sebagai raja merupakan peran yang menjadi wakil Allah yang menjalankan panggilannya sebagai stewardship dengan bertanggungjawab di hadapan sesama manusia dan alam. Jadi, manusia bukan penguasa atas alam, namun diberi tanggung jawab untuk merawat dan memelihara alam. ${ }^{34}$

Konsep pelayanan seperti ini adalah sebuah pandangan holistik, yang mengungkapkan identitas manusia sebagai rekan sekerja Allah dengan tanggung jawab sebagai steward (pengurus) dari aneka jenis sumber daya alam dan lingkungan yang telah Allah percayakan kepada manusia. Hal ini menggabungkan tanggung jawab individu dengan tanggungjawab keluarga dan masyarakat untuk bersama-sama membangun Taman Tuhan - yaitu masyarakat, ciptaan dan lingkungan dengan penuh tanggung jawab. Inilah paradigma sebagai orang percaya, mengusahakan dan memelihara harus dalam batas penatalayanan yang bertanggung jawab (stewardship), bukan kepemilikan (ownership). Manusia perlu tahu bahwa ciptaan Allah yang lain juga diciptakan oleh Allah dengan tujuan tertentu dan tentu saja mereka memiliki nilai yang pantas untuk diperlakukan baik dan dijaga keberadaanya. Inilah sebenarnya kesadaran ekologi yang perlu dipupuk oleh setiap manusia, yaitu menganggap ekologi sebagai

\footnotetext{
${ }^{33}$ Gerhard Von Rad, Old Testament Theology Vol. I (New York: Harper and Row, 1987), 11.

34 Jefri Hina Remikatu, 'Teologi Ekologi: Suatu Isu Etika Menuju Eskatologi Kristen', CARAKA: Jurnal Teologi Biblika Dan Praktika, 1.1 (2020), 65-85, https://doi.org/10.46348/car.v1i1.12.
} 
rumah bersama bagi semua makhluk hidup yang perlu dibangun atas dasar kebergantungan satu sama lain. ${ }^{35}$

Mengusahakan dan memelihara alam adalah bentuk manusia bertanggung jawab terhadap talenta yang telah dianugerahkan Tuhan kepada manusia. Allah telah memberikan mandat bahwa alam dapat diusahakan dan dikelola untuk dimanfaatkan dan dilipatgandakan hasilnya bagi kelangsungan hidup semua mahluk. Oleh sebab itu, perlu diingat bahwa alam wajib dipelihara dengan baik dan dan hasil serta keuntungan yang diperoleh dari alam, sebagian dapat dikembalikan sebagai deposit (renewable) terhadap alam dan juga secara bijak dipergunakan untuk keperluan siapapun yang membutuhkan. Sebab perlu diingat bahwa kesewenang-wenangan dalam memanfaatkan dan mengelola sumber daya alam merupakan salah satu penyebab utama dari kerusakan alam, sebab manusia yang terus merasa kurang dan rakus akan terus pula mengambil kebutuhan mereka dari alam dengan konsep dan cara yang tidak bertanggung jawab dan cenderung tamak.

\section{Kesimpulan}

Secara biblikal, makna mengusahakan dan memelihara Taman Eden dalam konteks Kejadian 2:15 berarti mengembangkan dan memanfaatkan segala sesuatu yang Tuhan sediakan di dalam Taman Eden sebagai habitat manusia, baik itu sumber daya alam ataupun alam itu sendiri agar semuanya itu mempunyai nilai tambah untuk dapat menunjang kehidupan bagi manusia di masa kini maupun masa yang akan datang. Tentu saja Allah menyediakan segala sumber daya yang dapat dikembangkan secara maksimal supaya manusia dengan hikmat dan akal budi yang Allah telah berikan juga dapat memeliharanya dengan menghargai apa yang Tuhan sediakan bagi manusia di Taman Eden. Manusia bukanlah sebagai pemilik atau penguasa Taman Eden, karena Allah adalah Sang Pemilik. Manusia hanya sebagai mitra kerja Allah yang bertugas untuk mengelola dan mengerjakan apa yang telah dimandatkan Allah untuk mengusahakan Taman Eden dengan penuh kerelaan, kesadaran, kasih dan pelayanan sebagai bentuk pengabdian dan ibadah kepada Tuhan.

Analisa terhadap frasa mengusahakan dan memelihara Taman Eden melahirkan temuan teologis sebagai konstruksi bagi orang percaya dalam pelayanannya dan tanggung jawabnya untuk terus mengolah dan melestarikan lingkungan. Orang percaya sebagai pribadi yang paham akan makna mengusahakan dan memelihara Taman Eden harus diikuti dengan sikap yang mencerminkan menghargai dan solidaritas dengan alam. Menghargai alam berarti menghargai Allah sebagai Sang Pemberi Anugerah, sedangkan sikap solidaritas berarti sikap yang tidak egois. Sikap solidaritas atau tidak

\footnotetext{
${ }^{35}$ Nirwasui Arsita Awang, Yusak B Setyawan, and Ebenhaizer L Nuban Timo, 'Ekoteologi Fungsi Hutan Oenaek: Penyimpangan Paradigma Ekologis Menuju Perilaku Eksploitatif', GEMA TEOLOGIKA: Jurnal Teologi Kontekstual Dan Filsafat Keilahian, 4.2 (2019), 135-154, https://doi.org/10.21460/gema.2019.42.423.
} 
egois ini menunjukkan manusia yang berbalik dari sikapnya yang rakus dan serakah terhadap alam, dimana yang semula memandang alam sebagai objek saja yang harus dieksploitasi dan dikelola sekehendak hati, justru dapat berbalik menjadi pribadi dengan sikap nyata yang mencerminkan kepedulian terhadap lingkungan.

\section{Referensi:}

Arthur, Kay. The New How to Study Your Bible: Discover the Life-Changing Approach to God. Oregon: Harvest House Publishers, 1994.

Awang, Nirwasui Arsita, Yusak B Setyawan, and Ebenhaizer L Nuban Timo. "Ekoteologi Fungsi Hutan Oenaek: Penyimpangan Paradigma Ekologis Menuju Perilaku Eksploitatif." GEMA TEOLOGIKA: Jurnal Teologi Kontekstual Dan Filsafat Keilahian 4 no. 2 (2019): 135-154. https://doi.org/10.21460/gema.2019.42.423.

Banks, Robert J. God the Worker: Journeys into the Mind, Heart and Imagination of God (Valley Forge: Judson, 1994)

Barth, Christopher. Theologia Perjanjian Lama 3. Jakarta: BPK Gunung Mulia, 2005.

Boeker, T.G.R.Bahasa Ibrani Jilid I. Batu: STT “I3”, 1992.

Boulton, Matthew Myer. God Against Religion: Rethinking Christian Theology through Worship. Grand Rapids: Michigan, 2008.

Brown, Francis. The New Brown-Driver-Briggs-Genesius Hebrew English Lexicon. Massachusetts: Hendrickson Publishers, 2001.

Brown, Lester. Tantangan Masalah Lingkungan. Jakarta: Yayasan Obor, 1999.

Chenu, M. D. The Theology of Work: An Exploration. Chicago: Regnery, 1966.

Evans, David J. Biblical Holism and Agriculture: Cultivating Our Roots. California: William Carey Publishers, 2008.

Friberg, Timothy. Analitical Lexicon of the Greek New Testament. Trafford Publishing. Gesenius, H.W.F. Gesenius' Hebrew-Chalde Lexicon to the Old Testament. Grand Rapids: Michigan, 2000.

Hagner, Donald A. World Biblical Commentary Vol I. Texas: Word Books Publishers, 2005.

J.L.Abineno. Manusia Dan Sesamanya Di Dalam Dunia. Jakarta: BPK Gunung Mulia, 2003. Mounce, William D. The Analytical Lexicon to the Greek New Testament. Grand Rapids: Michigan, 2000.

Northcott, Michael. The Environment and Christian Ethics. Cambridge: Cambridge University Press, 1996.

Owens, John Joseph. Analitical Key to the Old Testament Vol I. Grand Rapids: Baker Book House.

Patora, Marianus. "Peranan Kekristenan Dalam Menghadapi Masalah Ekologi." Jurnal Teruna Bhakti 1 no. 2 (2019): 117-27. http://ejournal.stakterunabhakti.ac.id/index.php/teruna/article/view/19. 
Rad, Gerhard Von. Old Testament Theology Vol. I. New York: Harper and Row, 1987. Remikatu, Jefri Hina. "Teologi Ekologi: Suatu Isu Etika Menuju Eskatologi Kristen." CARAKA: Jurnal Teologi Biblika Dan Praktika 1 no. 1 (2020): 65-85. https://doi.org/10.46348/car.v1i1.12.

Richardson, Alan. The Biblical Doctrine of Work. London: SCM Press, 1994.

Speiser, E.A. The Rivers of Paradise. Festschrift: Johannes Friedrich, 1959.

Steck, Hannes. World and Enviromnent. Nashville: Abingdon, 1980.

Stott, John. Issues Facing Christian Today. London: Marshall Morgan and Scott, 1984. Sunarko, A., and Eddy Kristiyanto. Menyapa Bumi Menyembah Hyang Ilahi: Tinjauan Teologis Atas Lingkungan Hidup. Yogyakarta: Kanisius, 2012.

Telaumbanua, S. "Pak Gereja Dalam Konteks Lingkungan Hidup Suatu Refleksi Terhadap Markus 16:15." Jurnal Shanan 4 no. 1 (2020): 41-56. http://ejournal.uki.ac.id/index.php/shan/article/view/1767.

Utomo, Bimo Setyo. 'Konsep Bekerja Sebagai Ad Majorem Dei Gloriam : Sebuah Upaya Pemenuhan Sacred CallinG'. Excelsis Deo: Jurnal Teologi, Misiologi, Dan Pendidikan 3 no. 2 (2019), 1-12. https://ejournal.sttexcelsius.ac.id/index.php/excelsisdeo/article/view/12.

White, Lynn. The Historical Roots of Our Ecological Crisis. New York: Harper and Row, 1994.

Zaluchu, Sonny Eli. Biblical Theology: Pembahasan Metodologi Dan Pendekatan Biblika Dalam Membangun Teologi PL Dan PB Yang Alkitabiah. Semarang: Golden Gate Publishing, 2017. 